\title{
THE IMPLEMENTATION OF NAHDLATUL ULAMA'S MODERATION PHILOSOPHY IN TREATING ISLAMIC FUNDAMENTALISM IN BANDAR LAMPUNG
}

Maulana Mukhlis, ${ }^{1}$ Ahmad Robi Ulzikri, ${ }^{2}$ Angger Widianto ${ }^{3}$

(1)Fakultas Ilmu Sosial dan Ilmu Politik Universitas Lampung, Bandar Lampung ${ }^{(2,3)}$ Pascasarjana Universitas Lampung email: maulanamukhlis1978@gmail.com, ahmad.robiulzikri@gmail.com, anggerwidianto01@gmail.com

Abstract: The Islamic fundamentalism movement has metamorphosed into a serious threat to the existence of multiculturalism in Bandar Lampung. This movement turned into a social and educational movement that penetrated educational institutions in Lampung. It transformed into a campus organization. Not only the state, Islamic religious-based civil society organizations with moderate views such as Nahdlatul Ulama often intersect directly with Islamic fundamentalism groups. The Islamic purification brought by this group has often become a space for friction with Nahdlatul Ulama (Henceforth: $N U)$. Moreover, there are study forums on-campus that discuss Islamic law and the caliphate (Khilafah) system as the Unitary system of the Republic of Indonesia. This has become a point of controversy with NU groups that accept Pancasila as the final foundation of the state. This study aims to find out how Nahdlatul Ulama Bandar Lampung City through its basic philosophy faces the contradiction of the Islamic fundamentalism movement and what challenges are faced by $N U$ with the Islamic fundamentalism group in Bandar Lampung. Theresearch method used is descriptive qualitative in which data are obtained through interview techniques. The results showed the contradiction of NU Bandar Lampung against Islamic fundamentalism groups holding on to the basic philosophy, namely tawassuth and i'tidal, tasamuh, and tawazun. Besides, community activities based on strengthening 
moderatism of Ahlussunah wal Jamaah annahdliyyah, and the attitude of tolerance among religious communities are based on the attitude of serving the people (fii khidmatil ummah). Future challenges for NU Bandar Lampung include internal challenges (increasing the quality of resources and the identity of the NU) and external challenges (environment and global change).

الملخص: تحولت حركة الأصولية الإسلامية إلى تهديد خطير لوجود حياة التعددية الثقافية

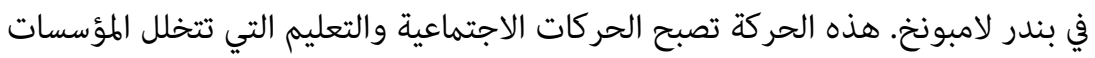

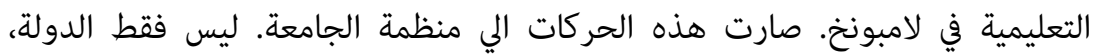

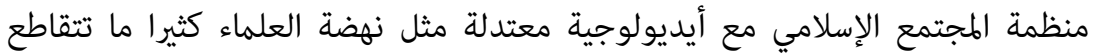

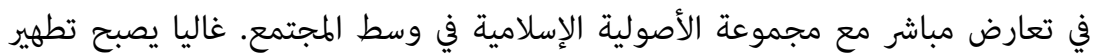

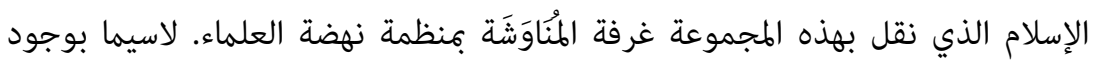

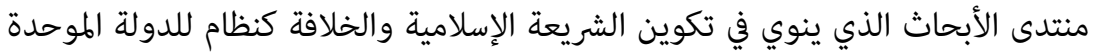

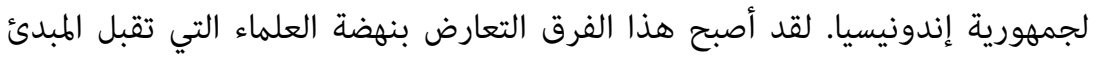

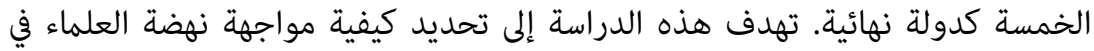

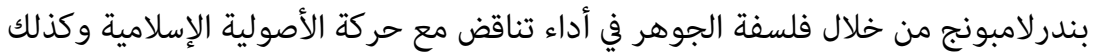

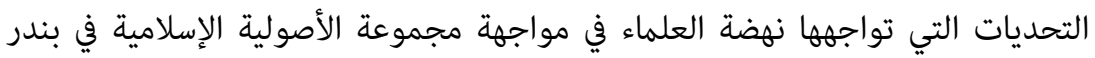

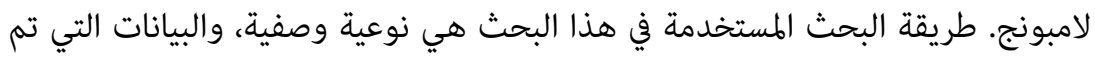

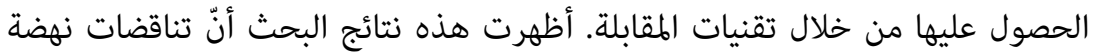

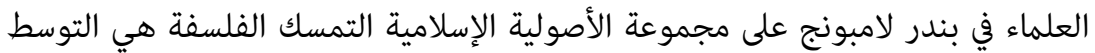

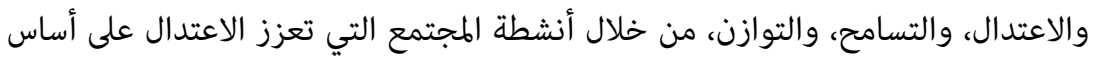

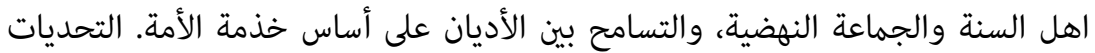

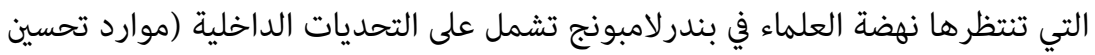

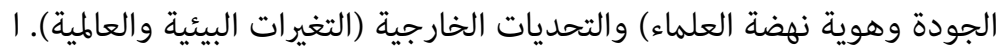

Abstrak: Gerakan fundamentalisme Islam telah bermetamorfosa menjadi sebuah ancamam serius terhadap eksistensi kehidupan multikulturalisme di Bandar Lampung. Gerakan ini bermetamoforsis menjadi gerakan gerakan sosial dan pendidikan yang merasuk ke dalam lembaga-lembaga pendidikan di Lampung. Ia menjelma menjadi organisasi kampus dan bahkan mengkooptasinya. Tidak hanya negara, organisasi masyarakat sipil berbasis agama Islam dengan faham moderat seperti Nahdlatul Ulama kerap bersinggungan langsung dalam 
kontradiksi terhadap kelompok fundamentalisme Islam di tengah masyarakat. Purifikasi Islam yang dibawa kelompok ini sering menjadi ruang gesekan dengan NU. Terlabih adanya forumforum kajian di kampus yang mewacanakan syariat Islam dan khilafah sebaga sistem negara Kesatuan Republik Indonesia. Hal ini menjadi titik gegesakan dengan kalangan NU yang menerima Pancasila sebagai Dasar negara yang sudah final. Penelitian ini bertujuan untuk mengetahui bagaimana vis a vis Nahdlatul Ulama Kota Bandar Lampung melalui falsafah dasarnya dalam melakukan kontradiksi terhadap gerakan fundamentalisme Islam serta tantangan yang apa saja yang dihadapi NU dalam vis a vis dengan kelompok fundamentalisme Islam di Bandar Lampung. Metode penelitian yang digunakan adalah deskriptif kualitatif, data diperoleh melalui teknik wawancara. Hasil penelitian menunjukan kontradiksi NU Bandar Lampung terhadap kelompok fundamentalisme Islam berpegangan pada falsafah dasar yaitu tawassuth dan i'tidal, sikap tasamuh, dan sikap tawazun, melalui kegiatan-kegiatan masyarakat yang bersifat penguatan sikap moderatisme berdasarkan Ahlussunah wal Jamaah annahdliyyah, sikap toleransi antar umat beragama berlandaskan pada sikap mengabdi kepada umat (fii khidmatil ummah). Tantangan kedepan bagi NU Bandar Lampung meliputi tantangan internal (peningkatan kualitas sumberdaya dan identitas ke-Nu-an) dan tantangan eksternal (lingkungan dan perubahan global).

Keywords: basic philosophy, moderation, Nahdlatul Ulama, islamic fundamentalism.

\section{INTRODUCTION}

The National Counterterrorism Agency (BNPT), in November 2017, had released data on radicalism in all provinces in Indonesia. The results showed that Lampung Province was included in the five provinces with the highest number of religious-motivated radicalism. The five provinces were Bengkulu (58.58\%), Gorontalo (58.48\%), South Sulawesi (58.42\%), Lampung (58, 38\%), and North Kalimantan (58.30\%). Meanwhile, the Lampung Province Terrorism Prevention Coordination Forum (FKPT) in 2016 had also 
mapped as many as six districts/cities in Lampung which had the highest level of vulnerability to being exposed to radicalism/religious fundamentalism. The six areas include the city of Bandar Lampung, Pringsewu, Central Lampung, North Lampung, South Lampung and East Lampung. FKPT also described several group compositions in Lampung that were exposed to the highest understanding of religious radicalism. The $63.6 \%$ were high school graduates, $16.4 \%$ were college graduates, and $5.5 \%$ were students who dropped out of college.

This condition was strengthened by the arrest of three suspects involved in the Jamaah AnsharutDaulah (JAD) network and suspected of having been in membership of the Islamic State of Iraq and Syria (ISIS) by Densus 88 in Bandar Lampung City on Monday, October 14,2019 . It was previously known that on March 9, 2019, Densus 88 had also succeeded in arresting perpetrators who were suspected of following hardline religious teachings and being exposed to religious fundamentalism in Kedaton District, Bandar Lampung. This incident has indicated Bandar Lampung as one of the areas listed in the record of the presence of the religious fundamentalist movement. It is not only in Lampung, but it is also in Indonesia.

In response to this issue, the role of resistance (vis a vis) seems that religious fundamentalism will be quite difficult to overcome by merely relying on the government. The state, in this case, the government, can optimize the role of civil society. Both are actors who directly intersect in countering fundamentalism religion. The handling of religious fundamentalism carried out by the state is still fixated on a prolonged technical level such as security, and there is still very little substantive handling through the active role of the community. The implication is that the issue of religious fundamentalism continues to roll like a snowball. Its portrait is that the issue of fundamentalism and radicalism that often becomes a sexy political issue at every election moment. The importance of the involvement of community organizations is considered very critical. If we reflect on the reality, the government itself has limited resources in terms of material, humans, technology, community participation, ${ }^{1}$ and the relationship among communities.

1 Miftahul Huda, "Islam Dan Civil Society (Dalam Konteks Ke-Indonesia-An)," Jurnal Fikri 1, no. 1 (June 2016): 6. 
Bandar Lampung, since the establishment of the NU organization in 1964, is one of the oldest cities that have been established in Lampung Province. There are seven branches of NU that have been established in Lampung such as Teluk Betung, Kota Bumi, Menggala, Krui, Sukarame, Kota Agung, and Talang Padang. Nahdlatul Ulama (NU) as the largest Islamic organization in Indonesia has positioned itself as an organization that is consistent in defending national values, including maintaining the integrity of the nation through counter-radicalism and fundamentalism which can damage the integrity of the nation. The emergence of several phenomena of the religious fundamentalism movement in Bandar Lampung has prompted religious-based civil society organizations such as NU to contradict the religious fundamentalist movement in various activities directly in the community through the pulpit of sermons, majlis ta'lim, recitation forums, and socio-religious studies. Thus, the escalation of counter-radicalism and fundamentalism movements that occurred in Bandar Lampung is certainly different from other areas in Lampung.

Studies of Islam and the doctrine of Islamic teachings on the campus in the city of Lampung are carried out by campus da'wah institutions or similar to student activity units that handle religious learning to students. The forum, which is supposed to be the practice of religious courses, has instead become the same doctrine of a rigid and even political understanding of Islam. Besides that, it is also done through study forums which are regularly carried out in several mosques and learning assemblies. On the other hand, the NU congregation voiced moderate attitudes by respecting multiculturalism as well as by promoting preaching with various approaches. NU emphasizes the importance of being moderate in religion to create a harmonious life in society and focuses on Da'wah by promoting unity and integrity to maintain diversity as a blessing for the Indonesian nation.

Both two streams of Islamic thought above, where one is fundamental and the other is the moderate NU, create a war of opinion in the public sphere. The discourses and narratives that appear in the pulpits seem to shout to each other. This makes Bandar Lampung a location for the struggle for the influence of discourse and religious understanding. 
The correlation of civil society and country in this context such as $\mathrm{NU}^{2}$ and the government in carrying out the counter-movement of religious fundamentalism has been explained by Cohen and Arato that civil society can interact with the state in the form of an opinion formation movement or influence policy through discussion activities and democratic processes in achieving the common good, both in political and state affairs. ${ }^{3}$ On the other hand, NU has a basis for thinking on which its members act in a moderation concept called by Greeg Fealy ${ }^{4}$ as a basic philosophy or in Cholid's concept ${ }^{5}$ as a principle of action namely tawassuth and i'tidal (moderate), tasamuh (tolerance), and tawazun (balanced). This study aims to analyze how the basic philosophy is applied by NU Bandar Lampung in conducting counter-measures against the Islamic fundamentalism movement in Bandar Lampung, as well as how NU faces challenges of Islamic religious fundamentalism in Bandar Lampung in the future.

The method used in this research is qualitative with a postpositive approach. The author uses this approach to obtain natural and indepth research data. The Information is obtained through interview techniques. The interview technique is used to find out the things of the respondents in depth. The author conducted some interviews with the technique of purposive sampling by selecting various parties. They are the management of NU Bandar Lampung, the FKPT Secretary of the Lampung Province, and the community in the NU Bandar Lampung environment. The technique was chosen to consider that the data needed to answer the research questions that required a certain categorization. With purposive sampling, the author can dig and find answers in-depth on the right sample. The author conducted a qualitative data analysis in which the model of this analysis was carried out repeatedly until it was saturated. Each period of data collection includes data collection activities,

2 Masroer, Model Gerakan Civil Society Pada Ormas Muhammadiyah Dan Nahdlatul Ulama (Yogyakarta: Bitread Publishing, 2020), 3.

3 Andrew Arato and Jean L. Cohen, Routledge Handbook of Global Populism. Edited by Carlos de La Torre. Routledge Handbook of Global Populism (London \& New York: Routledge, 2018).

4 Greg Fealy, Ijtihad Politik Ulama: Sejarah NU 1952-1967, 1st ed. (Yogyakarta: LKIS Printing Cemerlang, 2003).

5 Nur Cholid, Pendidikan Ke-NU-an Konsepsi Ahlusunnah Waljamaah Anahdliyah, 1st ed. (Semarang: CV. Presisi Cipta Media, 2016). 
presentation of raw data, then the data is reduced and categorized, and relationships are made among these categories. The approach used in this study is the phenomenological approach. According to Campbell, phenomenology departs from the mindset of subjectivism which does not only look at a visible symptom but tries to explore the meaning behind the phenomenon. ${ }^{6}$ In this concept, Collin calls it an emphasizing research process of meaningfulness. Phenomenology as a philosophical stream as well as a method of thinking was introduced by Husserl, that started from the truth of phenomena as they appeared to be. ${ }^{7}$

\section{THE ISLAMIC RELIGIOUS FUNDAMENTALISM}

The discourse on religious fundamentalism in the Indonesian context certainly has a differentiation from fundamentalism in other countries. ${ }^{8}$ These differences are very complex, for example in historical, cultural, community, and geographic aspects. Therefore, the concept of fundamentalism needs to be treated comprehensively in every aspect. This means that the concept of fundamentalism needs to be translated as one that is radical in the perspective of its goals, extreme in its method perspective, and literal (textual) in the perspective of its closeness to religious texts. ${ }^{9}$ In the context of religion, fundamentalism is often interpreted as a movement or even religious understanding where it seeks to return to what is believed to be the basics or principles (fundamentals). Religious fundamentalism is also interpreted as a notion that seeks to re-enforce

${ }^{6}$ Kim Sydow Campbell, Coherence, Continuity, and Cohesion: Theoretical Foundations for Document Design, 2008, accessed January 11, 2021, http://site.ebrary. com/id/10784426.

7 Finn Collin, Social Reality (London: Routledge, 1997), 103-104.

8 Saskia E. Wieinga, "Women Resisting Creeping Islamic Fundamentalism in Indonesia," Asian Journal of Women's Studies 15, no. 4 (January 2009): 30-56, accessed December 19, 2019, http://www.tandfonline.com/doi/full/10.1080/12259276 .2009.11666077.

9 Eko Ariwidodo, "Shifting Paradigm of Modern Islam Fundamentalism as Islamized Space Autonomy in Indonesia," KARSA: Journal of Social and Islamic Culture 25, no. 1 (June 1, 2017): 249, accessed May 1, 2019, http://ejournal. stainpamekasan.ac.id/index.php/karsa/article/view/1357. 
traditional (conservative) norms and beliefs of religion to face new understandings such as secularism, modernism, and humanism. ${ }^{10}$

In social and state life, the religious fundamentalism movement as a bearer of traditional religious values is very close to the presence of reformist or modern ideas. ${ }^{11}$ This is because the basic value held is that all life processes do not follow the basic values promoted by the emergence of religious teachings. So the religious fundamentalist movement groups try to carry the term back to what first appeared in religious teachings. In other words, rigidity in interpreting activities that are textually incompatible with religion is considered a form of deviation. More specifically, Burhanuddin defines Islamic fundamentalism as an ideology that seeks to re-establish Islam as a political system in the life of the modern world. ${ }^{12}$ In other words, Islam is strived to become a comprehensive organic system that competes within the reach of other ideologies and state systems. This is definitely coloured through the formation of terms and conventional concepts, in which Islamic fundamentalism also creates a new view (paradigm) in which there are theoretical and empirical elements. ${ }^{13}$

From its history, religious fundamentalism contradicts to the presence of modernity toward the presence of the French industrial revolution which has major implications for the order of life. In the Islamic world, for example, the reaction of fundamentalism is also unavoidable. The Islamic world inevitably enters the swirl of social dynamics. ${ }^{14}$ This, if traced, is very much in line with their efforts in constructing a chain of strategic, economic, and military

${ }^{10}$ M. Taylor and J. Horgan, "The Psychological and Behavioural Bases of Islamic Fundamentalism," Terrorism and Political Violence 13, no. 4 (December 2001): 37-71, accessed October 14, 2019, http://www.tandfonline.com/doi/ abs/10.1080/09546550109609699; Baca juga Andre Vltchek, "The New Face of Indonesia's Islamic Fundamentalism: Pornography Ban Ignores the Starving” (n.d.): 7.

${ }^{11}$ Itzchak Weismann, "Modernity from Within: Islamic Fundamentalism and Sufism," Der Islam 86, no. 1 (January 2011), accessed December 18, 2019, https:// www.degruyter.com/view/j/islm.2011.86.issue-1/islam.2011.018/islam.2011.018.xml.

${ }^{12}$ Nunu Burhanuddin, “Akar Dan Motif Fundamentalisme Islam:Reformulasi Tipologi Fundamentalisme Dan Prospeknya Di Indonesia," Wawasan: Jurnal Ilmiah Agama Dan Sosial Budaya 1, no. 2 (2016): 199-210, https://doi.org/10.15575/ jw.v1i2.831.

${ }^{13}$ Nevzat Soguk, Globalization and Islamism: Beyond Fundamentalism, Globalization (Lanham, Md: Rowman \& Littlefield Publishers, 2011).

${ }^{14}$ Seyyed Hossein Nasr, "Islam in the Modern World: Challenged by the West, Threatened by Fundamentalism, Keeping Faith with Tradition" (n.d.): 713. 
territories for the new European countries. In this discourse, Islamic fundamentalism can be understood as an answer to certain social groups and political elites in the Islamic community towards institutions, concepts, and ideas that have emerged in the modern world. ${ }^{15}$ The term fundamentalism itself was first used to refer to evangelical Christians in America wherein the nineteenth century (XIX) seriously attempted to apply a literal understanding of the use of the Bible purely by rejecting Darwin's theory which was popular at that time. At that time, the literalist fundamentalist group was labeled as naive considering that the rigid literalistic doctrine was considered as a primitive culture. Religious fundamentalism is also often identified with conservative Protestant clergy. This shows that the presence of religious fundamentalism at that time was intended to counteract liberal groups who tried to reinterpret the Bible in the concept of modern knowledge.

Burhanuddin, who was influenced by previous theorists, then classified the three roots of the birth of religious fundamentalism, esp ecially Islam, namely classical fundamentalism, modern fun damentalism, and post-modern fundamentalism. The author agr ees on this differentiation considering that the historical roots cannot be separated from the time series in which fundamentalism developed with its various characteristics.

First, the root of classical fundamentalism cannot be separated from the history of Ibn Taimiyyah (1263-1328) which carries the concept of purifying faith through the jargon that was carried, namely al-Ruju 'ila al-Qur'an wa al-Sunnah, or known well by the term "back to Quran and Sunnah". The Taimiyyah movement is also known by the term muhyi athar al-salaf or "reviving the teachings of the pious salaf ulama", which means a practice of religious teachings practiced by Rasulullah Saw and the generations that followed include the friends, tabi'in and tabi' al-tabi'in. Ibn Taymiyah's figure has also become fundamental in the Islamic world for his thoughts on rationalism. This spirit then fosters resistance to all systems outside of Islamic principles. This movement was also what inspired some of Ibn Taimiyyah's followers of the caliber of Ibn Qayyim al-Jauziyah (1292-1350 AD), Muhammad Ibnu Abdul Hadi (d. 1343 AD), and

${ }^{15}$ Youssef Michel Choueiri, Islamic Fundamentalism: The Story of Islamic Movements, 3rd ed. (London: Continuum, 2010). 
al-Dzahabi (673-748 H) through the intelligence movement. This then influenced the Wahabi movement which began to emerge in the middle of the 18th century AD in Saudi Arabia. Wahabi founded by Muhammad bin Abdul Wahab (1703-1792) is well-known as a very organized movement. His thinking was influenced by Ibn Taimiyyah's teachings even though there were differences in principle between the two. If Ibn Taymiyah was in motion against all forms of heresy, the worship of saints, and the pilgrimage to holy food, while Muhammad bin Abdul Wahab and his followers implemented it through practical action. Muhammad bin Abdul Wahab and his followers also expanded the movement through military instruments from Nejed to the Hejaz to Mecca and Medina. It is not only the Wahhabi movement that was influenced by Ibn Taymiyyah during the classical period of Islamic fundamentalism. ${ }^{16}$

Apart from that, other movements such as Jihad Sakoto in Nigeria led by Shaykh Ustman bin Muhammad Fudi (1754-1817) whose motive was not much different from what Wahabi, which is purification of religion through political movements to form a government system with Islamic law called the Khilafah Sokoto. In this case, the author does not fully agree on generalizations on behalf of Islam in some political movements that are more conservative or called radicals. Apart from the Wahabi and the Sokoto caliphate movement, Ibn Taymiyyah's virus of thought also constructed the thoughts of the activists of the Mahdi movement in Sudan led by Muhammad bin Abdullah (1834-1885) with almost the same motive, namely upholding Islamic law in the state government system. There are still several other movements that were also influenced by the thoughts of Ibn Taymiyyah during the period of classical Islamic fundamentalism.

Second, the roots of modern fundamentalism are characterized by a period around the 18th and 19th centuries. The characteristics of fundamentalism in this period are marked by various motives, namely colonialism, the motive of the modernism movement, and motives in response to reforms. The motive of colonialism was not only oriented towards controlling natural resources. Furthermore, Western colonialism towards eastern countries did not only indirectly have

\footnotetext{
${ }^{16}$ Burhanuddin, “Akar Dan Motif Fundamentalisme Islam:Reformulasi Tipologi Fundamentalisme Dan Prospeknya Di Indonesia.”
} 
implications for the aspects of militarism but also had implications for the missionary movement which influenced the map of the Islamic world in that period. The control of the western State over its colonies also influenced its socio-cultural life, so it is not surprising that it had caused some mixed reactions from the colonies. Then, on the motive of the modernism movement, fundamentalists criticized Muslims who were considered to experience aqidah crisis such as superstition, heresy, and khurafat. The figure of Muhammad Abduh and other modernist groups in this period attempted to reinterpret several normative texts to suit the development and change of social culture in the modern era, one of which was the use of a rational basis of thought to obtain flexible and developmental teachings era. Muhammad Abduh's thoughts later influenced the birth of the conservatism-traditionalism group which later transformed into a fundamentalism movement. Meanwhile, fundamentalism as a response motive for reforms in this period was marked by the emergence of movements that led to the empowerment of science, economy, and industry. So that the vortex of reform that occurred in the Islamic world at that time gave rise to the incitement of several Muslim groups in responding to the emergence of modernists. This reactionary movement was what some experts considered as the forerunner of the emergence of the fundamentalist movement in that period. ${ }^{17}$

Third, the root of post-modern fundamentalism was marked by the emergence of political movements (even armed military) to fight the control (hegemony) of Western countries over the world which was considered to be a large Islamic State which was increasingly strengthening its dominance over various regions, especially developing Muslim countries. Sayyed Hossein Nasr explained that the movement was originally found in Saudi Arabia and eventually transformed into various forms. The 1960s was the peak of frustration in the Muslim world because of the desire to emulate the West. However, Western domination was not easy for the Muslim world to realize its ambitions. After that, some Islamic organizations were established which in principle were to realize this dream, for example, the Muslim Brotherhood (Ikhwan al-Muslimin) in Egypt, and Jamaat al-Islami in Pakistan. After that, other organizations emerged such

${ }^{17}$ Ibid. 
as Hizb al-Tahrir, Jama'ah Islamiyah in Egypt, Jama'ah Islamiyyah in the Southeast Asia region, the Taliban Movement in Afghanistan, the al-Qaidah al-Islamiyah Movement in the Middle East, the FIS party in Algeria, and other organizations. ${ }^{18}$

These three root forms of fundamentalism at least can provide a picture that the period of the emergence of religious fundamentalism especially Islam appeared and developed in different cultural and social conditions with various motives even though in principle they acted in the name of purifying religion and fighting for Islam amid the hegemony of western countries over Islam. ${ }^{19}$ Today's religious fundamentalism has undergone a substance shift and even tends to have a negative connotation. Islamic fundamentalism is synonymous with conservative Islamic groups and even has a pejorative meaning (bad/degrading). Islamic fundamentalist groups are considered as radical groups, dissidents, anarchism and terror, acts of intimidation, in achieving their goals. On the other hand, there are not a few Muslims who also object to embedding "fundamentalists" in Islam which is considered a friendly religion for all people. The presence of this fundamentalist group has also received opposition, for example from the state, which views this movement as disturbing national stability. Besides, contradictions are also carried out by other Islamic groups and organizations that resist to the conservative ideas which are considered radical amid plural and multicultural country.

As a concept and a movement, Islamic fundamentalism cannot be separated from the radical Islamic movement. Both are Islamic movements that are of one accord in tune. Just like Islamic fundamentalism, Islamic terms and conceptualism do not come from the womb of Islam but are imported products from the West. Until now, there has been no agreement among Islamic observers regarding the appropriate term to describe the Islamic radicalism movement. Fazlur Rahman labeled this movement as a neo-revivalism movement or neo-fundamentalism, a movement that has an anti-Western spirit. ${ }^{20}$ Rahman views fundamentalists cynically. Fundamentalist groups are

${ }^{18}$ Nasr, "Islam in the Modern World: Challenged by the West, Threatened by Fundamentalism, Keeping Faith with Tradition."

${ }^{19}$ Beverley Milton-Edwards, "Islamic Fundamentalism since 1945” (n.d.): 175.

${ }^{20}$ Ahmad Asroni, "Radikalisme Islam Di Indonesia: Tawaran Solusi Untuk Mengatasinya," RELIGI: Jurnal Studi Agama-Agama 2, no. 1 (2008): 17; Baca juga Ahmad Asrori, "Radikalisme di Indonesia: Antara Historisitas dan Antropisitas," 
considered as superficial and anti-intellectual and their thinking does not originate from the Quran and the traditional Islamic intellectual culture. ${ }^{21}$ However, the term fundamentalist for Esposito feels more provocative and even pejorative as a movement that was once attached to Christianity as a literary, static, and extreme group. In turn, fundamentalism often refers to past lives, and fundamentalism is often equated to extremism, political fanaticism, political activism, terrorism, and anti-Americanism. Therefore, John L. Es Posito prefers to use the term Islamic revivalism or Islamic activism which has roots in Islamic tradition. ${ }^{22}$

Oliver Roy mentioned that the Islamic movement that is oriented towards the implementation of sharia is Fundamentalist Islam, which is shown by the Ikhwanul Muslimin movement, Hizb al-Tahrir, Jama'ah Islamiyah, and Islamic Salvation Front (FIS). ${ }^{23}$ The most important characteristic of Radical Islam which is also referred to as fundamental Islam is its literal approach to Islamic sources (alQuran and al-Sunnah). Fundamentalist literalism appears in their unwillingness to carry out rational and intellectual interpretations because they are actually narrow and very ideological interpreters when they make interpretations. This literalism coincides with the spirit of scripturalism, even though Leonard Binder categorizes nonscriptural fundamentalism for fundamentalist thinkers like Sayyid Qutb. ${ }^{24}$ In more detail, fundamentalist Islam is generally characterized by several basic characteristics such as literary interpretation of the text of the Quran and Hadith, no separation between the religious domain (private) and the state domain (public), no place for religious

KALAM 9, no. 2 (February 23, 2017): 253, accessed June 5, 2020, http://ejournal. radenintan.ac.id/index.php/KALAM/article/view/331.

${ }^{21}$ Fazlurrahman dalam Biyanto, "Fundamentalisme Dan Ideologi Islam Modern," Jurnal PARAMEDIA 7, no. 2 (April 2006): 17.

${ }^{22}$ John L. Esposito, Unholy War: Teror Atas Nama Islam (Yogyakarta: Ikon, 2003).

${ }^{23}$ Dikutip Fakhrurrazi, "Islam Radikal Antara Pemikiran Dan Gerakan: Analisis Kajian Dalam Perspektif Keberagamaan," 3, last modified 2008, accessed August 12, 2018, www.//imsakjakarta.files.wordpress.com.

${ }^{24}$ Baca Leonard Binder, Islamic Liberalism (Chicago: The University of Chicago Press, 1988). 
freedom, as well as everything that 'un-Islamic' needs to be replaced by 'a more Islamic' system. ${ }^{25}$

Chouieri identified the characteristics of Islamic revivalist movements, or radical Islamic movements, namely: (a) returning to the original Islam, purifying Islam from local traditions and foreign cultural influences; (b) encouraging free reasoning, ijtihad, and refusing taqlid; (c) the urges to move from areas dominated by infidels (dar al-kufr); (d) believing in the existence of a fair leader and a reformer. ${ }^{26}$

Radical and reactionary characteristics can be seen as another attribute of Islamic fundamentalism. The radicalist and reactionary attributes are the political dimensions of Islamic fundamentalism. The naming of Islamic radicalism is based on two reasons. First, this term is an ideological phenomenon, whose approach must be done by focusing on the ideological meaning and ignoring its social consequences and context. Second, the term does not refer to a single doctrine, group or movement, but only shows certain characteristics of some doctrines, groups, and movements. Therefore, the term Islamic radicalism is defined as the extreme group orientation of modern Islamic awakening (revival, resurgence, or reassertion). ${ }^{27}$

\section{NU'S BASIC PHILOSOPHY: FOUNDATION AND MEANING}

Starting from the concept of religious fundamentalism which has its motives and challenges to the efforts to contradict the movement, it is not an exaggeration to learn from Nahdlatul Ulama. As the largest Islamic organization in Indonesia, the efforts of the fundamentalism movement that emerged and grew in Indonesia inevitably would face one of the largest religious community organizations in Indonesia. NU has basic principles that position itself as a civil society organization in the life of the nation and state. In the relationship between the nation and the state, $\mathrm{NU}$ is synonymous with the principle of religious moderation which prioritizes and maintains the noble values of the

${ }^{25}$ Ismail Hasani and Et. All, Radikalisme Islam Di Jabodetabek Dan Jawa Barat: Implikasinya Terhadap Jaminan Kebebasan Beragama/ Berkeyakinan (Jakarta: SETARA INSTITUTE, 2011), 13.

${ }^{26}$ Choueiri, Islamic Fundamentalism.

${ }^{27}$ Biyanto, "Fundamentalisme Dan Ideologi Islam Modern," PARAMEDIA 7, no. 2 (2006): 18-19. 
nation. This is based on the awareness that Indonesia is a diverse and pluralistic country so that tolerance and mutual respect or moderation become the principles of attitude. This attitude is what then for the fundamentalist movement groups are often referred to as "Liberal" or they do not hesitate to call it superstition, heresy, and churafat.

It is the basic principles of religious understanding that then construct the religious attitude of the NU people, which is known as the basic philosophy of the NU movement. In social and religious movements, NU bases itself on the understanding of Ahl al-Sunnah wa al-Jama'ah (Aswaja) where its teachings provide interpretation of the Quran and Sunnah through their traditions in the teachings of the Yellow Book (Islamic classical book). So, it is not surprising that all strategic decisions related to organizations and people made by $\mathrm{NU}$ are always based on a fiqh approach. Classical fiqh literature from medieval scholars influenced the construction of the understanding of the ulama' (Kyai) which was then transmitted to the community through the students. The clear scientific principles that lead to the te achings of Muhammad Saw. also legitimize the validity of the teachings adhered to by the NU people themselves.

Several philosophies are used by NU in religion, society, nation, and state. One of these philosophies is contained in the adage:

$$
\text { ״المحافظة على القديم الصالح و الاخذ بالجديد الاصلح" }
$$

This philosophy has become a guideline for NU not only at the level of thought but also in terms of behavior, both organizationally (jam>iyyah) as well as in the context of members (jama>ah). This philosophy requires NU as an organization and its congregation to always maintain a tradition that brings benefit under the Shari>a and takes new things that can bring greater benefit. This philosophy requires that all thoughts and actions must be oriented for creating benefits, such as justice, unity, togetherness, harmony, and other good values as a necessity in social life. On the other hand, NU tries to dispel harms, both in individual and social life.

NU's grip on thoughts and attitudes is derived from the alQur'an, al-Sunnah, Ijma', and Qiyas which is also formulated in the principles of fiqh contained in the mu'tabar books in NU circles. Among the laws of figh that are relevant and which are used by NU include the following rules: 


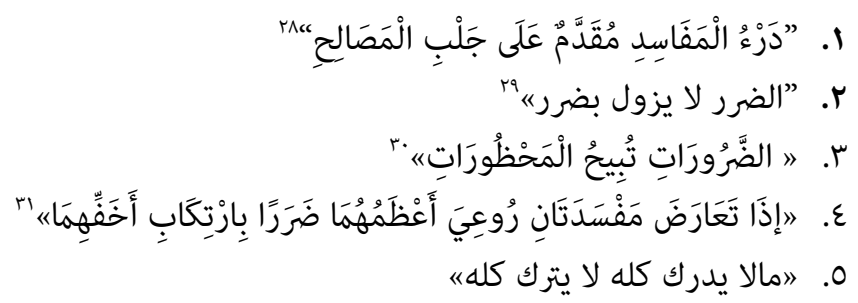

Ap art from adhering to the above principles, at least several concepts are used by NU, namely Shad al-Darai> (dispelling harmful things). Dzari ah linguistically means tools. In the context of Islamic law, dzari rah means a tool that can cause harm to benefit. More broadly, in this case, dzari'ah means a tool or intermediary which is legally permissible but can bring harm which is forbidden. There are three kinds of $d z a r i$ 'ah. First, dzari'ah must be driven away and avoided because it is certain that it will cause damage. This dzari'ah is something that scholars agree to be avoided. The second is dzari'ah which is likely to cause harm. The third is dzari' ah which is less likely to cause harm and damage. ${ }^{32}$

These principles and concepts then produce the principle of action in the form of a wise, flexible, and moderate attitude (tawāsut). Thus, NU puts forward a dialogue and cooperation approach in maintaining stability and balance between religious life and national life.

Three main points of thought underlie NU's understanding of moderation; 1) ukhuwah Islamiyyah (brotherhood of fellow Muslims),

${ }^{28}$ Baca juga Ḥasan Muhammad al-'Atțāar, Ḥāsyiyah a;- 'Atțār 'Ala Syarh al-Jalāe al-Maḥallì 'Ala Jam 'Il Jawami' (Digital Library, al-Maktabah al-Syāmilah al-Iṣdār al-Tsānī, n.d.), III/207; Sa'ad bin Nāṣir al-Sasarī, Syarh Manzhūmah Al-Qawā'id alFiqhiyyah Li al-Sa'dī (Digital Library, al-Maktabah al-Syāmilah al-Iṣdār al-Tsānī, n.d.), I/50.

${ }^{29}$ Imām Jalāluddīn Abdurrahmān As-Suyūṭī, Al-Asybah Wa al-Nadzā'ir Fì Qawā'idi Wa Furū' Fiqh al-Syāfi 'iyah (Riya: Maktabah Nazzār Al-Baz, 1997), I/86.

${ }^{30}$ Imam Abul Abbas Ahmad bin Idris Ash-Shonhaji Al-Qorofi, Al-Furuq/ Anwarul Buruq Fi Anwa'il Furuq (Beirut - Lebanon: Darul Kutub Al-Ilmiyah, 1998), VII/383; al-Sasarāi, Syarh Manzhūmah Al-Qawā'id al-Fiqhiyyah Li al-Sa'd̄̄, V/371; Baca juga Syaikh Abdurrahmān bin Nāṣir al-Sa'di, Al-Qawā'id Wal Ușūl (Digital Library, al-Maktabah al-Syāmilah al-Ișdār al-Tsānī, 2005), I/57.

${ }^{31}$ Aḥmad bin Muhammad al-Ḥanafī al-Ḥamawī, Ghamzu 'Uyūn al-Bașāir Fì Syarh al-Asybah Wa al-Nadzāir (Digital Library, al-Maktabah al-Syāmilah al-Iṣdār al-Tsānī, n.d.), III/109.

${ }^{32}$ Khalid bin 'Ali al-Musyaiqih, Al-Mu'amalāt al-Māliyah al-Mu'āṣirah (Digital Library, al-Maktabah al-Syāmilah al-Iṣdār al-Tsānī, 2005), 12-13. 
2) ukhuwah wathaniyyah (brotherhood among the nation's people), and 3) ukhuwah basyarriyyah (brotherhood of fellow humans). The implications of this thinking; 1) always creates a dynamic interactive di alogue between text (nash) and context so that it is hoped that the results of constructive-productive thinking will be achieved in building Islamic social situations and conditions, 2) develop religious at titudes (read: Islamic) that lead to its realization of maslahat al-'ammah (the benefit of the public) which is more in favor of crucial issues that develop in society, such as poverty, terrorism, the guaranteed practice of religion and belief without defamation, tr afficking of children and women, affordable education, labor, migrant labor, health services, improvement of living standards, price stability, and so on that people must receive a portion of the thinking of the Muslims so that national, public, and humanitarian issues become the main agenda of Islamic thought, 3) develop a positive tolerance for mutual respect based on the awareness of the pluralistic reality order as the main spirit of humanity and religion in socializing in an atmosphere of togetherness, 4) strengthen the framework of the construction of respect and respect for women fairly and avoid op pression and violence both physically and mentally, 5 uphold human rights in togetherness, prioritize dialogue, prioritize wisdom and good examples in solving humanitarian problems and stay away from all forms of violence in the name of sect and religion. ${ }^{33}$

The points above are characteristic of the moderate NU's way. Muchlis M. Hanafi interprets moderation (al-wasath) as a method of thinking, interacting, and behaving in a tawazun (balanced) manner in responding to two situations so that attitudes are found under Islamic principles and community traditions, namely balance in faith, worship, and morals. ${ }^{34}$ Meanwhile, Najib Burhani interpreted moderate Islam more on the meaning of the language that is as "mid-

${ }^{33}$ Alamul Huda, "Epistemologi Gerakan Liberalis, Fundamentalis Dan Moderat Islam Di Era Modern," de Jure Jurnal Syariah dan Hukum 2, no. 2 (2010): 193-194.

${ }^{34}$ Toto Suharto, "Gagasan Pendidikan Muhammadiyah Dan NU Sebagai Potret Pendidikan Islam Moderat Di Indonesia," ISLAMICA: Jurnal Studi Keislaman 9, no. 1 (2014): 88; Baca juga Tazul Islam and Amina Khatun, "Islamic Moderation" in Perspectives: A Comparison Between Oriental And Occidental Scholarships," International Journal of Nusantara Islam 3, no. 2 (2015): 71-72. 
position between liberalism and Islamism". People or organizations that are in the middle between liberalism and Islamism are moderate. ${ }^{35}$

Nahdlatul Ulama (NU) itself adheres to the understanding of $A h l$ al-Sunnah wa al-Jama'ah, that is, a way of thinking that chooses to take the middle path between the extremes aqli (rationalists) and the extremes naqli (scripturalist). Thus, the basic source of thought for NU is not only imprinted on the Qoran and Sunnah. Moreover, to interpret the Qoran and Sunnah requires the ability of reasoning with empirical reality. This kind of thinking refers to thoughts in the field of theology such as Abu Hasan al-Asy'ari and Abu Mansur alMaturidi. Meanwhile, the application of the methods of al-Ghazali and Junaid al-Baghdadi is in the field of Sufism, which then integrates Sufism and Sharia.

Ahl al-Sunnah wa al-Jama'ah as a source of ideology has become the principle and good faith of the organization (jam 'iyah) as well as followers of NU, which in the history of Islamic theology is the result of the ijtihad of the ulama to find a middle way so that it does not get trapped in the principle of a tatharuf (extreme) approach to religion. In the social life of society, the principles and basic principles of religion are the approaches of the ulama in instilling the attitude of NU citizens so that they are always in a conducive and constructive religious corridor in the life of the nation and state in the midst of a pluralistic Indonesian society. Then Fealy wrote that these basic values are embodied in the concept of tawassuth and i'tidal, tasamuh, tawazun, and amar ma'ruf nahi munkar which are attitude principles in making decisions with the principles of policy, flexibility, and moderation. Wisdom is defined as taking conducive actions to gain be nefits and avoid losses. Flexibility is defined as NU's attitude that is more open and able to adapt to the times and events that are happening and will occur. Meanwhile, moderatism is an attitude of avoiding extreme action or being cautious. It tends to take a middle ground neither leftward nor rightward.

The attitude ofmoderatism (tawassuth) of NU can be characterized by the concept of $i$ 'tidal (being fair), tawazun (being balanced), and tasamuh (being tolerant), so that in its actualization, NU followers

${ }^{35}$ Ahmad Najib Burhani, "Pluralism, Liberalism and Islamism: Religious Outlook of the Muhammadiyah Islamic Movement in Indonesia" (Tesis, University of Manchester, 2007), 16. 
reject any form of extreme action or thought (tatharruf) which can cause deviations and eliminate the substance of Islamic teachings. This attitude for the Islamic fundamentalism movement groups is identical with conservative, tough, and rigid Islamic attitudes which often conflict directly in society because they consider that moderate NU principles are considered liberal and contrary to aqidah.

\section{THE PORTRAIT OF ISLAMIC FUNDAMENTALISM IN BANDAR LAMPUNG}

The development of religious fundamentalism in Lampung Province, which was strengthened by the release of the Lampung Province FKPT in 2016, positions Bandar Lampung as the most potential place for the development of religious fundamentalism. It is too shallow if you look at the potential factor for the spread of religious fundamentalism, especially in Bandar Lampung, which is only due to geographical factors, although it cannot be blamed. The strategic location of Lampung province as the gateway to Sumatra is only infrastructure and a side factor for the development of religious fundamentalism. The more substantive problem of this problem is the weakness of contradictions and protection by the state against the spread of fundamentalism through educational instruments, economics, and other aspects of life that have not been taken seriously. Besides, the role of large Islamic organizations through education and other sectors seems to be less rapid than the fundamentalist movement which has roots in almost all aspects of life. The most crucial thing is when this group has entered the public domain, such as the control over places of worship. The more extreme fundamentalist groups often have dared to carry out movements exclusively through activities that are limited only to their groups, where these activities are carried out in several mosques in the city of Bandar Lampung.

Herdaus as Secretary of the FKPT Lampung Province said that the activities and thoughts of the fundamentalist group movement in the city of Bandar Lampung are affiliated with the Ikhwanul Muslimin movement. What is more extreme from the thinking of this fundamentalist group is their willingness to prefer to die by defending the caliphate rather than having to admit Pancasila as the nation's id eology. FKPT Lampung itself has collaborated with the State Intelligence Agency (BIN), but the result is that there are indications 
that the religious fundamentalism movement has transformed into te achings in Islamic boarding schools in Bandar Lampung. The FK PT of Lampung Province in 2016 also mentioned that groups and figures from the religious fundamentalism movement in Bandar Lampung actively narrate raising support for the establishment of the state of Daulah Khilafah which has a legal basis for Islamic law and the ambition of changing the Unitary State of the Republic of Indonesia (NKRI) to the Islamic State of Indonesia (NII). It was then also recorded by the FKPT that Bandar Lampung is one of the places where movements affiliated with the Fajar Nusantara Movement (GAFATAR) have grown.

The strong desire for governance based on the Qur' an and Hadith is the ideal that the religious fundamentalism movement group hopes for in Bandar Lampung. This is not much different from the motives of the three roots of Islamic fundamentalism, which share the goal of purifying rigid religion. Even some Islamic boarding schools in Bandar Lampung which are affiliated with the fundamentalism movement tend to lead to puritan movements and even militancy. The motive is, through Islamic studies activities that are usually held regularly as well as education in Islamic boarding schools, to have a mission to regenerate a militant generation that runs Islamic law. This group not only rejects the democratic system which is considered the culture of a western country that is irrelevant to Islamic teachings, but furthermore they also reject the notion of pluralism which they think is lech er ous because they consider the existence of a true religion besides Islam.

Referring to the findings in the research conducted by the author, in principle, the Islamic fundamentalist movement group wants the presence and enforcement of Islamic law which tries to be realized through the method of da'wah and the education system. There is an assumption that the state has not been able to provide a solution to the social problems of the ummah with the large number of social inequalities felt by Muslims. So from these arguments, it raised a big agenda from religious fundamentalist figures, including in Bandar Lampung, through the narrative of upholding Islamic law both structurally and culturally. One of the agendas is to produce militant cadres. Indeed, it seems as if it cannot be separated from political content, but it cannot be denied that it has also occurred in 
the course of the fundamentalism movement from the classical era to the contemporary era today.

\section{BASIC PHILOSOPHY ACTUALIZATION: NU Bandar Lampung Movement in Facing Islamic Fundamentalism}

In the view of the NU Bandar Lampung Branch Management itself, the Islamic fundamentalism movement cannot be separated from the political content that set up its movement on behalf of Islam. It means that these stage practical differences in principles have been started between NU Bandar Lampung and the Islamic fundamentalism movement group in Bandar Lampung. For NU, the concept of Islam is a religion that gives love to all people (Rahmat li al-Alamin) or a religion that brings peace to all humans. Therefore, for NU Bandar Lampung, it is not justified if Islam is defined as violence in the implementation of its teachings, as well as in the practice of the social life of the nation and state. For NU Bandar Lampung, Islam itself is a religion that respects the principles of tolerance and respect for fellow citizens of different religions. So the view of the elite of NU Bandar Lampung considers that the emergence of Islamic fundamentalist in Bandar Lampung needs to be criticized in the context of ideology that they understand which are considered to impose unilateral truth through violence when dealing with people who have different views, people with ideologies that are not in line with Islam, or even Muslims themselves who do not agree with the group. Not only that, but the NU Bandar Lampung has also criticized the rigid literalist attitude of being rigid with superficial interpretations of the Quran in carrying out religious teachings so that the Islamic religious fundamentalism group rejects other different interpretations.

The c haracteristic of scriptural literalism (text) is the understanding of fundamentalists in rejecting the interpretation of the holy book of the Quran from moderate Muslims such as NU that usually translates the Quran not only based on textual interpretations of the Quran and Hadiths but also uses several methods such as ijma and qiyas by considering the situation and social changes (cont ext). Meanwhile, the fundamentalist group rejects all kinds of new interpretations of Islamic texts, which are considered by fundamentalists as teachings that have deviated from pure Islam. At 
a critical stage, Islamic religious fundamentalism in the view of the elite of NU Bandar Lampung is to respond firmly in the form of contra (diction and narrative) by rejecting conservative ideas on behalf of Islam but using a rigid literalist approach and based on doctrines that justify themselves or their groups. The views of the Islamic religious fundamentalism group for NU Bandar Lampung do not represent the characteristics of the Islamic religion at all or can damage its image.

The u se of the term "Vis a Vis" between NU and Islamic funda mentalism groups is something that is not excessive if it examines in the context of a perspective. Besides, the use of the word 'Vis a Vis' between NU and the fundamentalism group is not the author's intention to confront the two in an increasingly sharp contradiction. The Vis a Vis of the largest Islamic organization in Indonesia (NU) and the fundamentalist group, in reality, it cannot be disavowed. The term "Vis a Vis" in the context of NU has been used in Feillard's writing which writes how the relationship between NU and the state is in a long and parallel historical series between the two. However, in the practice, NU's Vis a Vis is not only with the state but also with fellow community organizations. This phenomenon is an interesting discourse. ${ }^{36}$

The Vis a Vis between NU Bandar Lampung and the Islamic religious fundamentalism group can certainly be read when the ideals of the Islamic fundamentalist group disagree with the ideology of the Indonesian nation. This group aims to uphold Islamic law in a country with this plural condition. The more extreme willing is the desire to replace Pancasila. It certainly doesn't go hand in hand with the movement of Nahdlatul Ulama which has ideas that can be said to be parallel to the Islamic fundamentalism group where NU tries to maintain Pancasila as the basis of the state and the principle of pluralism at the forefront as the largest religious mass organization that has contributed to the independence of the Indonesian nation. NU's consistency in maintaining the Pancasila ideology is then applied by NU through the principles of national sovereignty and the integrity of the Republic of Indonesia. The meaning of national sover eignty for Muslims is protecting the nation from various threats and potential for national disintegration. One of its forms is

${ }^{36}$ Lebih lanjut baca Andree Feillard, NU Vis a Vis Negara; Pencarian Isi, Bentuk Dan Makna (Yogyakarta: LKiS, 2009). 
the emergence of the caliphate movement, which seeks to replace Pancasila, the formation of an Islamic state, and other motives for disin tegration. Meanwhile, NU has proven to be able to maintain national harmony at the level of civil society or the state, through friendly and moderate preaching of Islam.

Seein $g$ the challenge of NU in its movement contradicting purit anism and rigid fundamentalism, it is a tough task for NU to fight against the puritan Islamic movement that has flourished in In donesia. These movements are affiliated with international organizations such as Hizb al-Tahrir Indonesia(HTI), Salafi (Wahabi), Shia, Ikhwanul Muslimin (IM), Jemaah Islamiyah, ISIS, to local mass organizations that often have direct contact with NU that is the Islamic Defenders Front (FPI) which is currently disbanded. These fundamentalist Islamic movements have almost the same long-term agenda; rebuilding the government-based Khilafah Islamiyah system, upholding Islamic law, aspiring to build a social order and a political system based on the foundation of Islamic faith, and rejecting the democratic system.

In Vis a Vis, the movement of NU in Bandar Lampung targets Islamic fundamentalism groups, especially those that act on behalf of Islam but have a political agenda by promoting enforcement of Islamic Sharia. The Secretary of PCNU of Bandar Lampung City said that what became the target group for NU Bandar Lampung was not based on the organization or the teachings it carried, but rather on the ideology of the movement which aimed to change the Republic of Indonesia and Pancasila. Besides, the mapping carried out by PCNU Bandar Lampung city showed that the fundamentalist movement that becomes the target of resistance (vis a vis) by PCNU Bandar Lampung City is an exclusive movement group in several mosques in the city of Bandar Lampung and a fundamentalist movement group that has actualized its movement in the form of social and economic activities affiliated with certain fundamentalist organizations. These two groups are what NU of Bandar Lampung is facing with contradicting in various forms. In the first group, it was carried out by building NU values in schools and Islamic boarding schools. Meanwhile, the contradiction in the economic aspects, NU Bandar Lampung with a large number of members chose not to 
use economic services or products sold by groups indicated in the religious fundamentalism movement.

Known well as the biggest social organization of religious communities in Indo nesia, NU has a big moral responsibility in realizing a peaceful life amid the plurality of the nation through the practice of the ideological values of Pancasila. One form of the great contribution of the NU movement as a pioneer of the practice of Pancasila as the principle of a pluralistic national and state life in the realm of religion and nationality is the formulation of the concept of behaving and acting within the framework of tawassuth and i'tidal (moderate), tasamuh (tolerance), and tawazun (balance). These values are consider ed capable of counteracting Islamic fundamentalism which undermines Pancasila.

Fealy's idea of the basic philosophy of NU refers to the NU Khittah from the 1984 Congress XXVII in Situbondo which contains the principles used by NU followers in making decisions, both social and political decisions based on wisdom, flexibility, and moderation. The political decision that is meant here is not a practical politics of interest only, but rather a national politics in which politics takes into account the benefit of the people in the long run. It was NU's social attit udes that had been formulated in the basic NU philosophy that Fealy then used in analyzing NU politics based on the long history betwe en NU and the state. In this research study, the moderate princ iple of NU according to Fealy is used by the author as an indicator in analyzing the actualization of the basic principles through a moderate attitude; (tawassuth, i'tidal), tolerance (tasamuh), and balanced (tawazun), especially in contradiction to Islamic religious fundamentalism whether actualized internally or externally. ${ }^{37}$

The first is to measure the basic philosophy of tawassuth and $i$ 'tidal in vis a vis between NU and the Islamic fundamentalism group in Bandar Lampung. The moderate principle in this context is interp reted as an attitude in the middle. The attitude in the middle means that NU has a strong stance, not joining the extreme groups, either right or left. The moderate concept promoted by NU is a form of accommodating all interests of groups, ethnicities, and religions within the frame of pluralism in Indonesia. In the internal structure of the Nahdlatul Ulama, the actualization of the philosophy

${ }^{37}$ Fealy, Ijtihad Politik Ulama: Sejarah NU 1952-1967. 
of ta wassuth, and i'tidal applied through the activities of study forums which is a part of NU structural organization study forum. NU Bandar Lampung also concentrates on empowering the people, espec ially in streng thening tawassuth and i'tidal for the younger generation through da'wah instruments called Jami'at al-Harakat al-Ulama fi Himayah which means the ulama org anization which aims to safeguard and care for the understanding of Ahl al-Sunah wa al-Jamaah al-Nahdliyyah including a briefing for NU students who are members of the Nahdlatul Ulama Student Association (IPNU) and the Wome n's Student Ass ociation (IPPNU) in educational institutions that are adjusted to the millennial generation movement approach. NU at the branch level is often in direct contact with the social life of the community at the grassroots level of Nahdliyyin residents and often comes into direct contact with groups with extremist views. This condition was then understood by the elites of NU Bandar Lampung to be massive in carrying out anti-religious fundamentalism discourses and strengthening the faith of $\mathrm{Ahl}$ alSunah wa al-Jama'ah.

NU's moderate attit ude is an effort to realize NU's goals as stated in Article 9 of 2015 of NU Memorandum of Association/ Articles of Association as an effort to implement the Islamic concept of Ahl al-Sunah wa al-Jamaah for the benefit of the people. The meaning of the four basic NU philosophical values is mufradat or the terminological meaning which is interpreted in Arabic as tawassuth and i'tidal, tasamuh, tawazun, and amar ma'ruf nahi munkar where these values are summarized in the NU creed values. However, the four values can be understood in the plural form, namely moderate attitude. Moderate is an attitude where NU is in the middle and does not side with any group.

Herda us, the secret a ry of the FKPT of Lampung Province, explained that Lampung Province is the fourth region in Indonesia with the highest potential for exposure to religious fundamentalism. One of the efforts to overcome this problem is through a religious moderation program. Herdaus said that NU's role in contributing to building religious moderation was very much felt in helping local governments' efforts to contradict religious fundamentalism.

The limitations of the FKPT Lampung in touching the grassroots level of community elements can be complemented by the role of 
NU Bandar Lampung with the resources owned by NU through the NU Islamic boarding school. It is a concrete form of counterfundamentalism by NU in protecting the Republic of Indonesia.

Meanwhile, based on the recognition of residents, it explains that the activities carried out by religious fundamentalist groups in Bandar Lampung in their daily lives do not show any differences with society in general. For example, the way of their worship is generally the same as the amaliyah practiced by NU, such as reciting surat yasin, tahlil, and qunut. The only significant difference is in the way they get dress differently. However, according to the confession of residents after the incident of the arrest of the terrorist suspect who had an allegiance with Jamaah Ansharut Daulah (JAD) on Friday 10 October 2019, in Tanjung Senang Village, Babinkamtibmas (police officers) massively appeal to the public to socialize the prevention of religious radicalism and terrorism. Residents also admitted that the suspects in terrorism cases that occurred in their neighborhood were migrants with the initial aim of working and not indigenous people who had lived for a long time.

The second is to measure the implementation of the basic philosophy of tasamuh in the vis-a-vis between NU and the Islamic fundamentalism movement group in Bandar Lampung. The attitude of tasamuh in NU's view can be manifest ed in the form of mutual respect for pluralism and national plural ism. In the context of the appl ication of values of tasamuh, NU Bandar Lampung can be present among the people not only within the scope of Islam but also across religions. Besides, interfaith activities which are translated as da'wah are not only about religious propositions, but rather a tasamuh attitude which explains that NU is an organization that focuses on " $f$ i khidmah al-ummah" which means "the organization that serves people". In the field of education, for example, the inculcation of tas amuh attitudes is conducted through a formal system, namely Madrasah Tsanawiyah (MTS) of NU and Madrasah Aliyah (MA) of NU which belongs to Mustasyar of PCNU Bandar Lampung City, KH. Hafiduddin Hanief. Then, in the aspect of interfaith relations, NU Bandar Lampung actively participates in peace declarations, for example, the anti-racial declaration of interfaith youths initiated by NU Bandar Lampung represented by the Ansor Youth Movement. 
It indicates that NU is a movement concerned with pluralism and respecting pluralism.

Values of tasamuh applied by NU are in line with the steps taken by the FKPT of Lampung Province which stated that the roots of the emergence of religious fundamentalism movements and notions come from intolerance. Thus, strengthening mass organizations and communities such as NU through interfaith tolerance activities is a preventive step for FKPT Lampung and NU Bandar Lampung as an effort to counter (vis a vis) against religious fundamentalism. The actualization of tasamuh attitude or the tolerance of the followers of NU Bandar Lampung is based on several things, namely $f i$ khidmah al-ummah (serving the people), ukhuwah Islamiyah (a relationship based on the affection of religious similarities), ukhuwah bashariyah (a relation ship bas ed on a $\mathrm{n}$ att itude of humanism), ukhuwah wathaniyah (a relationship built based on nationality and love for the country), as well as the concept of Islam as Rahmat li al-Alamin . The implementation of the activities carried out by NU Bandar Lampung is in line with the preventive steps taken by the FKPT. How ever, this is not an indicat or of success to counter religious fundamentalism groups because, in the reality, the phenomenon of religious fundamentalism grows rapidly in various ways.

The third is the basic philosophy of tawazun in Vis a Vis bet ween NU and Islamic Fundamentalism in Bandar Lampung. Etymologically, tawazun attitude is interpreted in a balanced way. The attitude of tawazun is the attitude of harmony between relationships of khidmah (service or dedication) in relationships among humans, and relationships with Allah Swt. In its actualization, NU Bandar Lampung has applied the attitude of tawäzun through an attitude that is not exaggerated in everything, and also through activities that are religious in nature that have implications for the community as well as accepts modernization reforms that are relevant to the nation's culture. Furthermore, the results of field observations also found that attitudes of tawazun actualization of NU Bandar Lampung are supported by the accessibility ability of the managers of the NU Bandar Lampung City in filling strategic positions in government agencies which indicate the ability to manage power in actualizing the basic philosophy of NU to counter religious fundamentalism. 
Another thing that supports the actualization of tawazun also comes from social capital in the form of public trust in the capacity of the NU c lerics of Band ar Lampung City to provide Islamic preachings that unite and promote national tolerance. The inclusion of several structural NU administrators within the scope of the government bureaucracy helps NU Bandar Lampung to actualize the attitude of tawazun between the people and the state. This attitude then complicates the movement of the Islamic fundamentalism group in Bandar Lampung. The presence of NU cadres with capacities in many aspects of life including the government bureaucracy certainly nar rows the space for the group to move. However, religious fundamentalism groups also did not remain silent by starting to enter into other spheres such as the economy in the form of business and services.

\section{READING NU'S CHALLENGES: The Understanding and The Movement of Fundamentalism in Bandar Lampung}

Challenges for the nation as well as challenges for NU today and in the future are the threat of religious fundamentalism issues to national disintegration in the form of a time bomb that without proper prevention it will one day lead to a polemic that has implications for national stability. Apart from that, theoretical problems, pluralism, and religion (religious diversity and plurality) are also serious challenges. NU, whose birth was historically motivated by the desire of most scholars to uphold the religion from the Wahabi group in Hijaz, aims to maintain the understanding of Ahl al-Sunah wa al-Jama'ah al-Nahdliyyah. Over time, NU was again faced with big challenges to fill and maintain Indonesia's independence (nationalism).

In the context of vis a vis between $\mathrm{NU}$ and the religious fundamentalism movement in Bandar Lampung, the authors classify two forms of future challenges, namely challenges from inside NU itself (internal factor) and challenges from outside (external factor). First, internal challenges are closely related to the quality of resources that exist within both NU administrators and followers universally. If we reflect on scientific knowledge, of course, it is no longer a question that needs to be questioned. This goes from the background that society at the grassroots level is often in direct contact with Islamic fundamentalist groups. 
Having good understanding will help society to protect them from fundamentalist groups. In contrast, the lack of knowledge at the grassroots level will make it easy for the fundamentalist groups to attack them. Thus, it is hard for them in the grassroots level to fight and debate in the term of religious dialectics with the literalist fundamentalism groups in interpreting Quran and Hadis rigidly. This is one of the reasons why the followers in the grassroots level are still easy to get carried away. For example, there are many Islamic boarding schools with the concept of Ahl al-Sunah wa al-Jama'ah al-Nahdliyyah in Bandar Lampung City, but they don't teach the thought (fikrah) of NU perfectly. The result is that many students do not have a good understanding about NU and do not follow what has been agreed by the previous NU Ulama. One of the cases that can be an example is that there are many students and the followers of NU participated in the reunion of 212 action even though NU structurally did not recommend to participate in that event. This then became the concern of PCNU Bandar Lampung to increase religious literacy among the grassroots of the NU community by strengthening aspects of education in Islamic boarding schools and religious understanding in the general public through regular recitation activities carried out by Kyai of NU in Bandar Lampung.

The internal challenges did not stop there. There is the differentiation of amaliyah or how to worship with Harakah and NU fikrah at the grassroots level of society. There are still residents who carry out activities and worship with amaliyah and methods that are identical to NU such as doing yasinan, tahlilan, and qunut but do not position themselves as part of NU citizens. The amaliyah (religious practice) of NU that lives in the community is not purely balanced with the way of thinking and movement promoted by the structural administrators of NU, in this case, the PCNU Bandar Lampung City. This is a serious challenge for the structural management of NU Bandar Lampung to restore the NU identity that is almost faded in the society. It is a big task for NU to restore its identity and proudly proclaim "I'm NU".

Second, external challenges come from environmental conditions and global conditions which are constantly changing. Since its formation, NU, with the predicate of traditionalist Islam, has inevitably transformed itself to keep up with the progress of 
the times. Mastery of technology and information has become imperative in adaptation efforts. However, the most important thing is not to eliminate NU's distinctive features and identity from its basic philosophy, but to keep in mind that religious fundamentalist groups are also massive using information technology instruments in their da'wah narratives. Besides, the control of mosques by Islamic fundamentalist groups needs a serious response from the NU Bandar Lampung structure to prevent the massive movement of religious fundamentalism in Bandar Lampung.

\section{CONCLUSION}

This study, with its shortcomings, including limited representation and the scope of the study locus, concludes that vis a vis of Nahdlatul Ulama, Bandar Lampung City, through its basic philosophy to contradict the Islamic fundamentalism movement in Bandar Lampung has answered research questions. The results of the discussion show that the contradiction of NU Bandar Lampung against Islamic fundamentalism groups adhering to basic philosophies such as tawassuth and i'tidal (tolerance), tasamuh attitudes, and tawazun attitudes, as well as through community activities that strengthen moderate attitudes based on Ahl al-Sunah wa al-Jamaah alNahdliyyah based on the attitude of serving the people (fi khidmat alummah). Meanwhile, the future challenges that must be faced for NU Bandar Lampung include internal challenges (improving the quality of resources and the identity of NU at the grassroots level) as well as external challenges (the environment and global change) that need to be addressed wisely.

\section{REFERENCES}

Al-Qarafi, Imam Abul Abbas Ahmad bin Idris Ash-Shonhaji. AlFuruq/Anwarul Buruq fi Anwa'il Furuq. Beirut - Lebanon: Darul Kutub Al-Ilmiyah, 1998.

Arato, Andrew, and Jean L. Cohen. Routledge Handbook of Global Populism. Edited by Carlos de La Torre. Routledge Handbook of Global Populism. London \& New York: Routledge, 2018. 
Ariwidodo, Eko. "Shifting Paradigm of Modern Islam Fundamentalism as Islamized Space Autonomy in Indonesia." KARSA: Journal of Social and Islamic Culture 25, no. 1 (June 1, 2017): 249. Accessed May 1, 2019. http://ejournal. stainpamekasan.ac.id/index.php/karsa/article/view/1357.

Asroni, Ahmad. "Radikalisme Islam di Indonesia: Tawaran Solusi untuk Mengatasinya.” RELIGI: Jurnal Studi Agama-Agama 2, no. 1 (2008).

Asrori, Ahmad. "Radikalisme di Indonesia: Antara Historisitas dan Antropisitas." KALAM 9, no. 2 (February 23, 2017): 253. Accessed June 5, 2020. http://ejournal.radenintan.ac.id/index. $\mathrm{php} / \mathrm{KALAM} /$ article/view/331.

Al-Suyūṭī, Imām Jalāluddīn Abdurraḥmān. Al-Asybah wa alNadzā'ir Fì Qawā'idi wa Furū' Fiqh al-Syāfi'iyah. Riya: Maktabah Nazzār Al-Baz, 1997.

Al-'Ațtāā, Hasan Muhammad. Ḥāsyiyah al-'Atțāa 'ala Syarh al-Jalāl al-Mahallī 'ala Jam 'i Jawami.' Digital Library, alMaktabah al-Syāmilah al-Iṣdār al-Tsānī, n.d.

Biyanto. "Fundamentalisme Dan Ideologi Islam Modern." PARAMEDIA 7, no. 2 (2006).

- "Fundamentalisme Dan Ideologi Islam Modern." Jurnal PARAMEDIA 7, no. 2 (April 2006).

Burhani, Ahmad Najib. "Pluralism, Liberalism and Islamism: Religious Outlook of the Muhammadiyah Islamic Movement in Indonesia." Tesis, University of Manchester, 2007.

Burhanuddin, Nunu. "Akar Dan Motif Fundamentalisme Islam:Reformulasi Tipologi Fundamentalisme Dan Prospeknya Di Indonesia." Wawasan: Jurnal Ilmiah Agama Dan Sosial Budaya 1, no. 2 (2016): 199-210. https://doi.org/10.15575/ jw.v1i2.831.

Campbell, Kim Sydow. Coherence, Continuity, and Cohesion: Theoretical Foundations for Document Design, 2008. Accessed January 11, 2021. http://site.ebrary.com/id/10784426. 
Cholid, Nur. Pendidikan Ke-NU-an Konsepsi Ahlusunnah Waljamaah Anahdliyah. 1st ed. Semarang: CV. Presisi Cipta Media, 2016.

Choueiri, Youssef Michel. Islamic Fundamentalism: The Story of Islamic Movements. 3rd ed. London: Continuum, 2010.

Collin, Finn. Social Reality. London: Routledge, 1997.

al-Sa'di, Syaikh Abdurrahmān bin Nāșir. Al-Qawā'id wa al-Ușūl. Digital Library, al-Maktabah al-Syāmilah al-Iṣdār al-Tsānī, 2005.

Esposito, John L. Unholy War: Teror Atas Nama Islam. Yogyakarta: Ikon, 2003.

Fakhrurrazi. "Islam Radikal Antara Pemikiran Dan Gerakan: Analisis Kajian Dalam Perspektif Keberagamaan." Last modified 2008. Accessed August 12,2018. www.//imsakjakarta. files.wordpress.com.

Fealy, Greg. Ijtihad Politik Ulama: Sejarah NU 1952-1967. 1st ed. Yogyakarta: LKIS Printing Cemerlang, 2003.

Feillard, Andree. NU Vis a Vis Negara: Pencarian Isi, Bentuk Dan Makna. Yogyakarta: LKiS, 2009.

al-Ḥamawī, Aḥmad bin Muḥammad al-Ḥanafì. Ghamzu 'Uyūn alBașāir Fì Syarh al-Asybah Wa al-Nadzāir. Digital Library, alMaktabah al-Syāmilah al-Iṣdār al-Tsānī, n.d.

Hasani, Ismail, and Et. All. Radikalisme Islam Di Jabodetabek Dan Jawa Barat: Implikasinya Terhadap Jaminan Kebebasan Beragama/ Berkeyakinan. Jakarta: SETARA INSTITUTE, 2011.

Huda, Alamul. "Epistemologi Gerakan Liberalis, Fundamentalis Dan Moderat Islam Di Era Modern.” de Jure Jurnal Syariah dan Hukum 2, no. 2 (2010): 178-194.

Huda, Miftahul. "Islam Dan Civil Society (Dalam Konteks KeIndonesia-An).” Jurnal Fikri 1, no. 1 (June 2016).

Islam, Tazul, and Amina Khatun. "Islamic Moderation" in Perspectives: A Comparison Between Oriental And Occidental 
Scholarships." International Journal of Nusantara Islam 3, no. 2 (2015): 69-78.

Leonard Binder. Islamic Liberalism. Chicago: The University of Chicago Press, 1988.

Masroer. Model Gerakan Civil Society Pada Ormas Muhammadiyah Dan Nahdlatul Ulama. Yogyakarta: Bitread Publishing, 2020.

Milton-Edwards, Beverley. "Islamic Fundamentalism since 1945" (n.d.): 175.

al-Musyaiqih, Khalid bin 'Ali. Al-Mu'amalāt al-Màliyah al-Mu'āṣ irah. Digital Library, al-Maktabah al-Syāmilah al-Iṣdār alTsānī, 2005.

Nasr, Seyyed Hossein. "Islam in the Modern World: Challenged by the West, Threatened by Fundamentalism, Keeping Faith with Tradition" (n.d.): 713.

al-Sașarī, Sa'ad bin Nāṣir. Syarh Manzhūmah Al-Qawā'id alFiqhiyyah Li al-Sa'dī. Digital Library, al-Maktabah alSyāmilah al-Iṣdār al-Tsānī, n.d.

Soguk, Nevzat. Globalization and Islamism: Beyond Fundamentalism. Globalization. Lanham, Md: Rowman \& Littlefield Publishers, 2011.

Suharto, Toto. "Gagasan Pendidikan Muhammadiyah Dan NU Sebagai Potret Pendidikan Islam Moderat Di Indonesia." ISLAMICA: Jurnal Studi Keislaman 9, no. 1 (2014): 81-109.

Taylor, M., and J. Horgan. "The Psychological and Behavioural Bases of Islamic Fundamentalism." Terrorism and Political Violence 13, no. 4 (December 2001): 37-71. Accessed October 14, 2019. http://www.tandfonline.com/doi/ abs/10.1080/09546550109609699.

Vltchek, Andre. "The New Face of Indonesia's Islamic Fundamentalism: Pornography Ban Ignores the Starving" (n.d.): 7.

Weismann, Itzchak. "Modernity from Within: Islamic Fundamentalism and Sufism.” Der Islam 86, no. 1 (January 
2011). Accessed December 18, 2019. https://www. degruyter.com/view/j/islm.2011.86.issue-1/islam.2011.018/ islam.2011.018.xml.

Wieinga, Saskia E. "Women Resisting Creeping Islamic Fundamentalism in Indonesia." Asian Journal of Women's Studies 15, no. 4 (January 2009): 30-56. Accessed December 19, 2019. http://www.tandfonline.com/doi/full/10.1080/12259 276.2009.11666077. 